\title{
COOPERATIVISMO E AGRICULTURA FAMILIAR: ALTERNATIVA DE TRABALHO E GERAÇÃO DE RENDA
}

\author{
Loyanne Lima Feitosa'; ${ }^{1}$ Fernando Michelotti ${ }^{2}$ \\ 1- Discente do Curso de Agronomia e bolsista de iniciação cientifica - loy_lima@ hotmail.com \\ 2- Msc. Professor da Universidade Federal do Pará- UFPA
}

RESUMO: A região sul e Sudeste paraense abrange cerca de 38 municípios. Sua ocupação é fruto da política governamental que incentivou populações de diversas regiões do Brasil a migrarem para o estado. Geograficamente localizada numa área de grandes projetos mineradores, produção agroextrativista, de constantes conflitos agrários entre pequenos camponeses, sem-terras com os latifundiários, pecuaristas e grandes produtores agrários, a região traz um histórico de mazelas com grandes desigualdades sociais e alto índice de concentração de renda que produz a marginalização de pessoas das camadas populares que não dispõem de condições mínimas de vida digna. Contudo, hoje há uma nova realidade do mundo do trabalho, as mudanças estruturais de ordem econômicas e sociais, ocorridas nas últimas décadas, fragilizaram o modelo tradicional de relação de trabalho capitalista caracterizado pelo trabalho assalariado instituído no final do século XIX. Esse contexto contribui para o surgimento de novos sujeitos sociais e para a construção de novos espaços institucionais. Sendo assim, a economia solidária encontra-se como alternativa para milhares de trabalhadores e trabalhadoras que buscam alterar suas condições de vida sob a forma de organização coletiva do trabalho nas mais diversas regiões. Diante disto, este trabalho, realizado com o apoio do Governo do Estado do Pará em convênio com a Secretaria de Emprego, Trabalho e Renda (SETER) que concedeu a bolsa de pesquisa, pretende analisar o cooperativismo no contexto da economia solidária dentro da Cooperativa Mista da Agricultura Familiar de Marabá (COOMFAMA). A pesquisa seguirá a linha de abordagem qualitativa e será aplicada em Janeiro de 2010 no assentamento Nova Esperança com os cooperados da COOMFAMA. Terá o ambiente natural como sua fonte direta de dados e o pesquisador como seu principal instrumento. Serão coletados dados descritivos; inclui transcrições de entrevistas e de depoimentos e atentará para o maior número de elementos presentes na situação estudada. A coleta de dados será através da observação, entrevista (questionário semi-estruturado) e análise documental, além de estudo detalhado das obras de autores como: Marx "O Capital: critica da economia política", livro1 volume1, com ênfase em relações de trabalho. Bem como Paul Singer "Introdução a Economia Solidária" e Marcos Arruda, que enfatiza em algumas de suas obras a questão do cooperativismo na esfera da economia solidária, e a auto-gestão em cooperativas como alternativa ao desemprego. Pretende-se discutir o contexto da economia solidária e da agricultura familiar local para entender como ocorreu a formação da Cooperativa Mista da Agricultura Familiar de Marabá (COOMFAMA), assim averiguar em qual contexto os agricultores procuram uma outra forma de estabelecimento economico na sociedade; entender quais são as estrategias da cooperativa e sua ação junto aos cooperados; compreender o que é cooperativismo e de que forma os seus principios agem como força motivadora da construção de uma outra lógica de produção; conhecer quais são as dificuldades da cooperativa em seguir os principios de economia solidária. A pesquisa almeja alcançar maior dimensão quando se propõe a ser uma ferramenta motivadora do cooperativismo a fim de contribuir para as políticas públicas voltadas para e agricultura familiar da região do Pará.

PALAVRAS-CHAVE: Cooperativa, economia solidária, incubadora. 